Agro-Science Journal of Tropical Agriculture, Food, Environment and Extension Volume 20 Number 1 (January 2021) pp. 9 - 14

ISSN 1119-7455

\title{
GLOBAL UTILISATION OF CEREALS: SUSTAINABILITY AND ENVIRONMENTAL ISSUES
}

\author{
${ }^{* 1}$ Olugbire O.O., ${ }^{2}$ Olorunfemi S. and ${ }^{1}$ Oke D.O. \\ ${ }^{1}$ Forest Economics \& Extension Services Department, \\ Forestry Research Institute of Nigeria, Jericho, Ibadan, Nigeria \\ ${ }^{2}$ Department of Sustainable Agriculture \& Food Security, \\ Royal Agricultural University, Cirencester, GL76JS, United Kingdom \\ "Corresponding author's email: olugbireolutoyin@gmail.com
}

\begin{abstract}
Over the years, cereals have been the major food consumed by humans and have also been used in animal diet and therefore highly commendable for playing a major role in the preservation of human race. Studies have shown that half of the total percentage of calories consumed in the world is from cereals while it is also the most traded agricultural crop at the international market. This motivates the need to assess its utilisation in the past, present and future. This review shows that much driven by the use of cereals are factors like consumption and dietary pattern of a person or country, technological advancement in adding value to it, income status, market forces of demand and supply, level of affluence and policy. The trend in global cereals utilisation since its domestication has indicated an upward one with bulk of it being consumed as food in developing countries while majority of it goes into feeding livestock in developed countries. Evidence from this study also shows that the per capita utilisation of cereals directly for food is exceedingly great in developing countries than developed countries which is an indicator of malnutrition when not balance with other nutrients as it was observed in Bangladesh where calorie intake of an adult is about 90\% from cereals. While there is a steady increase in global cereals utilisation due to its discovered industrial use as fuel, increased population and other factors, it will be expedient to focus on its sustainability and environmental issues that are likely to come up as a limitation to meet future demands.
\end{abstract}

Key words: demand, supply, environment, utilisation of cereals

\section{INTRODUCTION}

The importance of food in our society cannot be overemphasized. Beyond its need for hunger satisfaction, food is absolutely required for physiological functioning of the body. This necessitates the advocacy for balanced diet which subsumes the inclusion of all required nutrients from the six classes of food (carbohydrate, protein, vitamin, fat and oil, mineral salt and water) in their required amount for everyday meal (Fernie and Pitkethly, 1985). Among all that is required, carbohydrate accounts for a larger proportion in most diets because of its need for energy provision for other organs (such as brain and even cells down to systems) to function for effective day to day activities. Bulk of this carbohydrate can be obtained from cereals. Cereals are grain like food developed from the grass family with a scientific name called Gramineae (Wrigley, 2016). They are highly rich in carbohydrate with little of other basic nutrients. Examples include rice, wheat, maize, Sorghum, barley and millet. Most of these cereals are widely adopted as staple food in most parts of the world.
Rice is widely consumed in China, Vietnam, Bangladesh, India and Cambodia; maize which is also known as corn is most widely grown in USA, Mexico, China, Brazil, India; Sorghum is mostly grown and consume in Africa; and wheat is vastly utilised in China, India, Russia and USA (FAO, 2004). As observed in developing countries, most people depend largely on cereals for the supply of about $60 \%$ of calories needed with little protein to complement, while developed countries depend on it for about $30 \%$ of calories needed in their body (Awika, 2011). Even though the dependency of the developed countries on cereals is low in comparison to the developing countries based on direct human consumption, most of them still depend indirectly on cereals to feed livestock upon which they derive protein nutrient (Jones and Sheats, 2016). Between 1961 and 1965, 37\% of the cereals produced in developed countries are directly consumed as food by human while the remaining $67 \%$ accounted for feed formulation. This proportion changed from the initial to $28 \%$ for direct consumption while $72 \%$ goes into feed formulation between 1975 and 1977.

Please cite as: Olugbire O.O., Olorunfemi S. and Oke D.O. (2021). Global utilisation of cereals: sustainability and environmental issues. Agro-Science, 20 (1), 9-14. DOI: https://dx.doi.org/10.4314/as.v20i1.2 
This change is attributed to the increase in the number of high income earners whose diet has transformed to include more of protein in meals than carbohydrate as a mark of change in status in the society (Fernie and Pitkethly, 1985). However, in whatsoever ways cereal is being used, it is obvious that its significance across all countries cannot be overemphasized. In the United States of America (USA), for instance, maize was discovered to be a major ingredient in producing sweetener, food starch and ethanol. This has increased demand beyond that which exists for human consumption and feeding of livestock. As a result, prices of grains have increased, devaluing per capita consumption (Awika, 2011). Therefore, the diversified utilisation of cereals accompanying the historical consumption between human and livestock qualifies this review to assess the trend in global utilisation of cereals based on past and present uses with the inclusion of evaluating the environmental and sustainability issues to satisfy future demand.

\section{Past Global Utilisation Trend of Cereals: Consumption and Dietary Pattern with Main Drivers}

Arguably, the food items known to have aided civilization across all human races which facilitated mutual interdependency among countries through international agricultural trade are "cereals". Virtually everyone depends on cereal consumption in the past before the diversification into other uses began to set in variations in demand. To exemplify, Table 1 gives a clearer picture of the demand and utilisation of cereals between the intervals of 1961-1965 and 1975-1977 in developed and developing countries.

From Table 1, it is obvious that cereals are consumed less in developed countries compared to developing countries. Between 1961 and 1965, about $14 \%$ of the total cereals utilised were consumed by human in North America while the remaining 86\% was fed to animals, which was a replica of the consumption and dietary pattern in other developed countries. A perfect example was the case of USA in the 1890s up till 1960 where cereals (wheat) consumption was on the decline because people changed their meal menu to include more of meat. This change in consumption was encouraged by an increased income following economic growth at the time. This consumption pattern of wheat took another trend as it began to increase in 1972 till 1997 due to widespread of fast food joints and breakfast shops that used wheat flour. This was then accompanied by a further shift away from consuming wheat in the 1997 because of advocacy against excessive fatness, high expenses on energy, and other health issues arising from wheat consumption (Awika, 2011). According to Jones and Sheats (2016) and Awika (2011), USA ranks highest in world maize supply with a capacity of about $40 \%$ of world production but the bulk of it is used as animal feed with just $15 \%$ consumed by human with a per capita consumption of $15 \mathrm{~kg}$. The same was seen in sorghum where USA is the second largest producer after Nigeria but diverted all its sorghum to feeding animals until recently that research is considering the medicinal benefit associated with the grain. The only cereal that has gained good acceptance for direct human consumption in the developed countries especially in European Union (EU) is Oats due to its low cholesterol content that was certified following the campaign against cereals consumption in USA in 1997 (Jones and Sheats, 2016).

Contrary to the scenario observed in developed countries was the immense consumption of cereals as food by humans in developing countries, especially Africa between 1961-1965 (Table 1), where about $95 \%$ of cereals is being consumed by human and 5\% used in formulating livestock feed. According to Food and Agricultural Organization (FAO, 2015), although the global demand rate for cereals declined by $0.9 \%$ in 1990 from $1.9 \%$ in 1989 and $2.5 \%$ in 1970 s to $1 \%$ in 1990 due to decreasing rate of increase in world population followed by a rapid increase in the consumption of cereals in most Asian part of the world which has limited export, yet, the mean per capita consumption of cereals in developing countries had still risen between those periods. An example of this was seen in Central Africa, West Africa, East Africa, Far East and Asia where the calorie intake was far from that of the Northern part of the world, with the ratio of energy being derived from cereals remaining as high as possible with ridiculous variation in required amount of other food nutrient such as protein. To further assert this, the calorific intake from cereals in Bangladesh is as high as $90 \%$ which is a bit higher than $85 \%$ calorie intake in the Sahel, which reveals the disproportionate distribution in diet composition with deficiencies of other nutrients. (Fernie and Pitkethly, 1985). This affirms the report of Dako (1985), that cereals provide an average of $50 \%$ calories to Africans and more than $70 \%$ in some other developing countries of the world. The table below gives a record of world cereal utilisation from 1994 to 2019. The data in Table 2 shows that world cereal utilisation in 2018/19 was put at 2,688 million tonnes, which is a record higher than the previous years and it is around 33 million tonnes higher than in 2017/18. This implies that consumption of cereals is on the increase.

From Table 2, it can be inferred that there has been steady increase $(9.56 \%)$ in global cereal utilisation from 1799 million tons in 1994 to 1971 million tons in 2002 due to increase in the level of demand from the developing countries in accordance with the report of FAO (2015). While bulk of the cereals utilised in developing countries were consumed by humans, utilisation in the developed countries was more of feed formulation for livestock with a constant trend on cereal consumed as food. 
Between 1994/1995 and 1995/1996, the fall in global cereal utilisation which accounted for about 8 million tons was explained by a sudden rise in global price of cereals that could have hindered cereal exportation to developing countries for food consumption. However, this was counterbalanced by a reduction in the quantity of cereals used as feed in developed countries (39 million tons) in order to meet the demand from the developing countries. It is clear that between 1994 and 2004, one-fourth of cereals consumed as food in developing countries was being consumed as food in developed countries while the trend of cereals used as feed reflected the opposite. Estimates for other uses accounted mainly for waste and little for seeds in developing countries, while much goes into industrial use in developed countries. Generally, cereal utilisation increased within this period due to factors like increasing population, increased livestock production, change in dietary and consumption pattern, and increased importation due to shift from farming to oil boom in some developing countries, among others (FAO, 1996, 2019, 2020).

\section{Present Utilisation of Cereals with Projection}

Following the trend of cereal utilisation pattern from the 1960 s, it is clear that its main uses in developing countries are for human consumption, while its uses in the developed countries center on livestock feeds and industrial product, such as biofuel, ethanol, sweetener, plastic, medicinal syrups and many more.

According to the information in Figure 2, world cereal production in 2020 has been revised upward by 9.3 million tons and currently stands at almost 2,790 million tons, with the global output set to surpass the record-high reached in 2019 by as much as $3.0 \%$ (81.3 million tons). The forecast for world cereal utilisation in 2020/21 has increased to 2,735 million tons, just over 43 million tons (1.6\%) above the 2019/20 level (FAO, 2020).

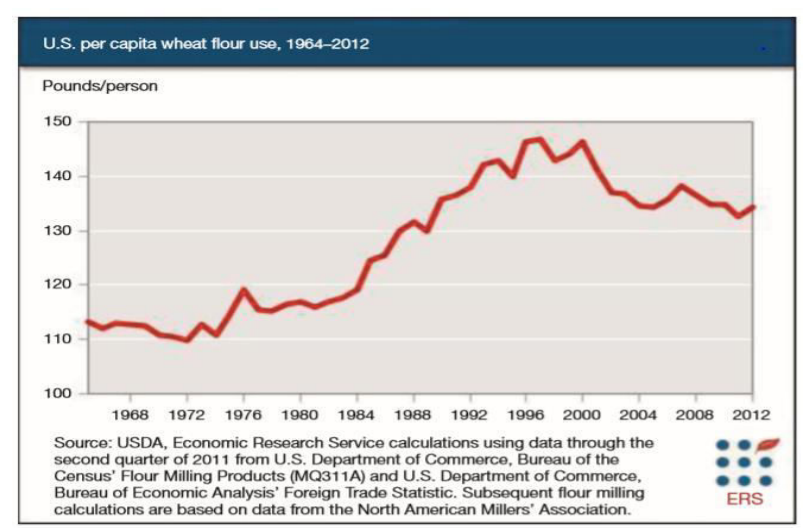

Figure 1: Trend in wheat flour use in USA from 1964 to 2012

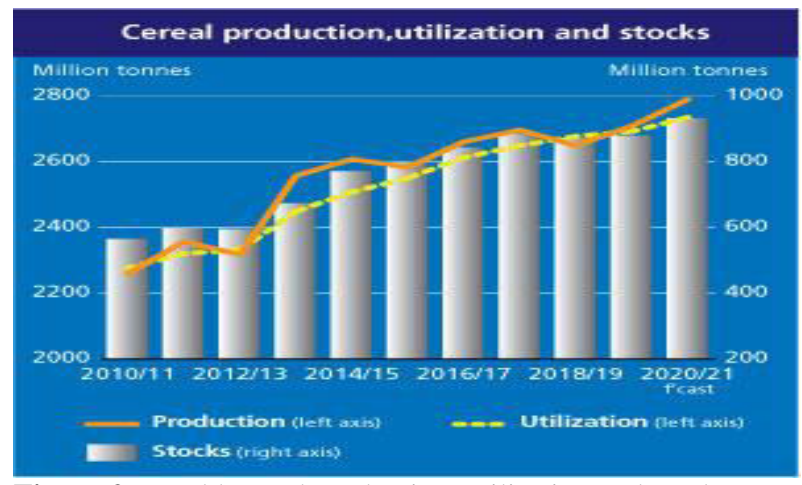

Figure 2: World cereal production, utilisation and stocks

Table 1: Utilisation of cereals as food (million tons) (Source: FAO, 1996)

\begin{tabular}{|c|c|c|c|c|c|}
\hline & & \multicolumn{2}{|c|}{ Human } & \multicolumn{2}{|c|}{ Animal } \\
\hline & & $1961-1965(\%)$ & $1975-1977(\%)$ & $1961-1965(\%)$ & $1975-1977(\%)$ \\
\hline \multirow{5}{*}{ Developed Countries } & Total & $159.5(37)$ & $164.1(28)$ & $266.7(63)$ & $413.0(72)$ \\
\hline & North America & $19.2(14)$ & $21.8(14)$ & $122.1(86)$ & $135.7(86)$ \\
\hline & Western Europe & $45.1(38)$ & $43.7(30)$ & $72.3(62)$ & $101.9(70)$ \\
\hline & Oceania & $1.6(43)$ & $1.9(42)$ & $2.1(57)$ & $2.6(58)$ \\
\hline & Eastern Europe \& the USSR & $69.5(52)$ & $70.1(31)$ & $63.6(48)$ & $155.4(69)$ \\
\hline \multirow[t]{6}{*}{ Developing Countries } & Total & $369.7(88)$ & $538.3(87)$ & $48.8(12)$ & $79.8(13)$ \\
\hline & Africa & $28.9(95)$ & $42.4(93)$ & $1.5(5)$ & $1.9(7)$ \\
\hline & Latin America & $28.7(68)$ & $42.8(59)$ & $13.6(32)$ & $29.6(41)$ \\
\hline & Near East & $25.3(78)$ & $39.1(77)$ & $7.3(22)$ & $11.9(23)$ \\
\hline & Far East & $150.6(98)$ & $213(98)$ & $2.6(2)$ & $5.0(2)$ \\
\hline & Asia Centrally Planned & $136.0(85)$ & $200.8(87)$ & $24.0(15)$ & $30.3(13)$ \\
\hline World Total & & $529.2(63)$ & $702.4(59)$ & $315.5(37)$ & $492.8(41)$ \\
\hline
\end{tabular}

Table 2: World cereal utilisation (million tons) from 1994 to 2019 (Source: FAO, 1996, 2004, 2019)

\begin{tabular}{|c|c|c|c|c|c|c|c|c|c|}
\hline & & $\begin{array}{l}1994 / \\
1995\end{array}$ & $\begin{array}{l}1995 / \\
1996\end{array}$ & $\begin{array}{c}1996 / \\
1997\end{array}$ & $\begin{array}{l}2001 / \\
2002\end{array}$ & $\begin{array}{l}2002 / \\
2003\end{array}$ & $\begin{array}{l}2003 / \\
2004\end{array}$ & $\begin{array}{c}2017 / \\
2018\end{array}$ & $\begin{array}{l}2018 / \\
2019\end{array}$ \\
\hline \multirow[t]{3}{*}{ Total Utilisation } & World & 1799 & 1791 & 1827 & 1947 & 1950 & 1971 & 2655 & 2688 \\
\hline & Developing countries & 1047 & 1079 & 1097 & 1181 & 1185 & 1213 & 1795 & 1821 \\
\hline & Developed Countries & 752 & 713 & 729 & 766 & 765 & 759 & 859 & 866 \\
\hline \multirow[t]{3}{*}{ Food Consumption } & World & 903 & 920 & 933 & 969 & 975 & 990 & 1135 & 1250 \\
\hline & Developing Countries & 740 & 754 & 767 & 795 & 801 & 816 & 902 & 920 \\
\hline & Developed Countries & 164 & 166 & 167 & 174 & 174 & 174 & 233 & 330 \\
\hline \multirow[t]{3}{*}{ Feed Use } & World & 646 & 614 & 633 & 714 & 710 & 711 & 926 & 945 \\
\hline & Developing Countries & 199 & 207 & 213 & 265 & 267 & 275 & 571 & 461 \\
\hline & Developed Countries & 447 & 408 & 420 & 449 & 443 & 436 & 355 & 484 \\
\hline \multirow[t]{3}{*}{ Other Uses } & World & 249 & 258 & 260 & 263 & 265 & 270 & 350 & 380 \\
\hline & Developing countries & 108 & 118 & 117 & 121 & 116 & 121 & & \\
\hline & Developed Countries & 141 & 139 & 142 & 143 & 149 & 148 & & \\
\hline
\end{tabular}


A shown in Table 3, estimates of consumption pattern of cereals in developing countries have remained almost the same up till date. The per capita consumption of cereals from 1984 to 2015 which is recent has been maintained at an average of $172 \mathrm{~kg}$ person $^{-1}$ year $^{-1}$ while its utilisation in the livestock and industrial sector has made a slight shift from $234 \mathrm{~kg}$ in 1984 to $265 \mathrm{~kg}$ in 2015 which is still higher than the per capita consumption of the developed countries across the years (FAO, 2003). Juxtaposing the per capita cereal utilisation for all uses in developing countries with developed countries, it is clear that utilisation is highly increasing in the latter when compared to the former at all periods. In $1974 / 1966,483 \mathrm{~kg}^{-1}$ person $^{-1}$ year $^{-1}$ was utilised for purposes other than food in developed countries which is widely far from $183 \mathrm{~kg}^{-1}$ person ${ }^{-1}$ year $^{-1}$ in developing countries. When progressively compared, in 2015,630 and $173 \mathrm{~kg}^{-1}$ person $^{-1}$ year ${ }^{-1}$ were used in developed and developing countries, respectively. Likewise, the forecast exhibits the same trend with the estimates increasing to $667 \mathrm{~kg}^{-1}$ person ${ }^{-1}$ year $^{-1}$ in non-food sector for developed countries which is far higher compared with $279 \mathrm{~kg}^{-1}$ person $^{-1}$ year $^{-1}$ in developing countries. This shows that the utilisation of cereals in a non-food manner dominates in developed countries while human consumption dominates in developing countries (FAO, 2003).

As reported by FAO (2018) and presented in Table 4 , the world cereals utilisation increased by 32.3 million tons from $2016 / 2017$ to $2017 / 2018$ while a forecast into this year (2018/2109 with $2017 / 2018$ as base year), based on reduced prices and excess supply, shows that consumption is expected to increase by 16.2 million tons with much emphasis on nations like Brazil, USA, Mexico, China and so on. This, however, shows the current status of cereals consumption across the globe.

Excerpts from OECD/FAO (2016) relate the influx of cereals due to a fall in price and sluggish increase in level of demand relative to past years as an omen for further fall in price of cereals globally (Table 5). Using $2013 / 2015$ as a reference point, the present dawdling economic growth, increasing stocks, low fuel price and high exchange rate are expected to retain cereal prices at low level which will have the implication of increasing production and stocks rate. On this note, world cereal supply is forecasted to increase by $12 \%$ come 2025 and relative to $2013 / 2015$ production, wheat supply will increase by $10 \%$ (71 million tons) with 10 million tons coming from India, China (7.9 million tons), USA (1.7 million tons) and many other increases in other wheat producing countries. This, however, is forecasted to be accompanied by a corresponding increase in utilisation with a global projection of $14 \%$ increase in wheat utilisation. Feed utilisation from wheat is forecasted to increase especially in China, Russia and Europe and wheat use as biofuel is expected to increase by $1.2 \%$ in the world by 2025. Likewise, maize utilisation is also expected to rise from $56 \%$ in $2013 / 2015$ to $60 \%$ by 2025 which was predicted to be mostly driven by increased feed utilisation due to prediction of growth of livestock industry in developing countries. The table below shows the prediction of future consumption and production of selected cereals from 2013 up to 2025 .

\section{Environmental and Sustainability Issues around Cereal's Production; Supply and Utilisation}

Agricultural production has led to environmental damage and other environmental issues in recent years. This is as a result of the growing demand of food due to increase in human population. Preproduction, production and post-production practices cause these environmental issues around the globe, including expansion in production to meet demand and cropping decisions that adversely affect the soil as well as on-farm and off-farm biodiversity (Stevenson et al., 2014). Production constraints to cereals production have been combated with methods that have negative impact on future production and environment. For example, the introduction of early maturing varieties of millet and sorghum has exposed the cereals to molds and fungi that now devastate harvest in some areas (Haussmann et al., 2012). The environmental problems arising from production of these cereals create constraints for further production.

Table 3: Per capita consumption of cereals: trend analysis (Source: FAO 2003; 2019)

\begin{tabular}{|c|c|c|c|c|c|c|c|}
\hline $\mathrm{kg}^{-1}$ person $^{-1}$ year $^{-1}$ & & $1964 / 66$ & $1974 / 76$ & $1984 / 86$ & $1997 / 99$ & 2015 & 2030 \\
\hline \multirow[t]{3}{*}{ World } & Cereals - food consumption & 147 & 151 & 168 & 171 & 171 & 171 \\
\hline & Cereals - all uses & 283 & 304 & 335 & 317 & 332 & 344 \\
\hline & Total food $\mathrm{kCal} /$ Person/day & 2358 & 2435 & 2655 & 2803 & 2940 & 3050 \\
\hline \multirow[t]{3}{*}{ Developing Countries (excluding China) } & Cereals - food consumption & 141 & 150 & 172 & 173 & 173 & 172 \\
\hline & Cereals - all uses & 183 & 201 & 234 & 247 & 265 & 279 \\
\hline & Total food $\mathrm{kCal} /$ Person/day & 2054 & 2152 & 2450 & 2681 & 2850 & 2980 \\
\hline \multirow[t]{2}{*}{ Developed Countries } & Cereals - food consumption & 136 & 136 & 147 & 159 & 158 & 159 \\
\hline & $\begin{array}{l}\text { Cereals - all uses } \\
\text { Total food kCal person }{ }^{-1} \mathrm{day}^{-1}\end{array}$ & 483 & 504 & 569 & 588 & 630 & 667 \\
\hline
\end{tabular}

N.B: Cereal Food Consumption includes the grain equivalent of beer consumption and of corn sweeteners

Table 4: Global cereal utilisation from 2014 to 2018: World cereal market (million tonnes) (Source: FAO, 2018)

\begin{tabular}{|c|c|c|c|c|c|}
\hline & $2014 / 2015$ & $2015 / 2016$ & $2016 / 2017$ & $2017 / 2018$ & $2018 / 2019$ \\
\hline Production & 2568.9 & 2542.6 & 2613.4 & 2648.2 & 2607.0 \\
\hline Supply & 3185.2 & 3223.2 & 3310.3 & 3372.7 & 3363.1 \\
\hline Utilisation & 2500.7 & 2521.7 & 2577.4 & 2609.7 & 2625.9 \\
\hline Trade & 378.2 & 391.7 & 405.5 & 408.5 & 406.2 \\
\hline Ending stock & 680.6 & 696.9 & 724.5 & 756.0 & 735.5 \\
\hline
\end{tabular}


Table 5: World cereal projection (Source: OECD/FAO (2016)

\begin{tabular}{llllccccccc}
\hline \multirow{2}{*}{ Wheat } & Metric tonnes & Average 2013/15est & 2016 & 2017 & 2018 & 2019 & 2020 & 2023 & 2025 \\
& Production & 720.3 & 721.7 & 733.2 & 739.8 & 747.3 & 753.9 & 775.6 & 791.3 \\
Maize & Consumption & 709.9 & 727.7 & 733.4 & 740.4 & 746.7 & 752.2 & 773.7 & 789.6 \\
& Production & 1014.3 & 1006.0 & 1041.3 & 1048.5 & 1059.8 & 1075.1 & 1117.1 & 1146.0 \\
\multirow{2}{*}{ Rice } & Consumption & 986.7 & 1024.9 & 1038.6 & 1060.1 & 1062.8 & 1073.7 & 114.7 & 1143.4 \\
& Production & 493.4 & 503.6 & 510.5 & 517.7 & 524.7 & 531.0 & 549.7 & 562.6 \\
& Consumption & 490.8 & 510.3 & 512.1 & 519.0 & 525.8 & 532.3 & 550.5 & 563.2 \\
\hline
\end{tabular}

\section{Negative Ecological Trend}

(Deforestation, Flooding, Water logging)

Bommarco et al. (2013) stated that the decisions made on farming production may hinder future production because of the inhibition of valuable ecosystem services such as pest control and pollination. Tilman et al. (2001) and Lambin and Meyfroidt (2011) asserted that about 2.7-4.9 million ha of land used in crop production may be needed to feed the world's population by the year 2030. This implies that there would be more of forest land that would be converted land used for crop production of which cereals production would be a major one because of its high demand for human and animal consumption. According to Kissinger et al. (2012), 80\% of global deforestation had been attributed to conversion of these forests to agriculture and this would mean more of deforestation in future years as demand increases. Deforestation is known to threaten the existence of useful species and microorganism necessary for sustainable environment. According to International Union for Conservation of Nature (IUCN, 2014), $53 \%$ of terrestrial species have been assessed as threatened resulting from the negative impact of agriculture and this would most likely increase in the future as demand for cereals and other agricultural products increase. Apart from deforestation, growing demand of cereals could also lead to air pollution which is harmful for humans. For example, flooding of rice fields leads to $\mathrm{CH}_{4}$ emission (Wakatsuki et al., 2011; Reay et al., 2012). Maize production has also been associated with the usage of fertilizers and this has led to the emission of GHGs released both from its manufacturing and usage (Reay et al., 2012). Climate change is a clear implication of human activities especially agriculture. Chakraborty and Newton (2011) stated that human production activities have been influencing global climate and had also decreased the availability of non-renewable resources.

\section{Pest and Diseases Breakout}

Another environmental problem associated with cereals production (rice in particular) is the increased insect borne diseases among people and communities in areas in Africa and Asia adjacent to flooded rice producing areas. (Larson et al., 2010).

\section{Sustainability}

\section{Increasing Population Growth}

Due to rapid growth in population, there is an increase in the demand for food and this has necessitated the need for resource use efficiency and reduction in environmental problems caused as a result of nutrient losses, land degradation, climate change and other related agro-ecological problems. This calls for sustainable production, which will meet the present-day demand for cereals without jeopardizing the ability of generations to come to meet their own need for cereals. This calls for production techniques that would be environmentally friendly and yet meeting the increasing demand for cereals. Higher demand as well attracts use of machineries to improve production which in the long-run contribute to soil degradation.

\section{Variability in Climatic Conditions}

Due to the present climate change and environmental stress, one of the ways to sustain the production of cereals is the mixture of varieties of the grains. Doring et al. (2015) stated the importance of increasing genetic diversity in crops and stating that the importance includes yield stability and adaptability, reduction in disease distribution, increased competitive ability with weed, and efficiency in nutrient uptake. This was affirmed by Mile et al. (2006) who reported that winter barley mixture comprising four and two components performed better than average of individual pure line component and the best yielding pure stand variety was not the best contributor to the mixture. This calls for future breeds of cereals which would be genetic varieties rather than pure breeds.

\section{Use of Innovative Technologies}

Innovations such as sustainable intensification, ecological intensification and integrated agriculture have been introduced in different parts of the world (Foley et al., 2011; Tilman et al., 2011; Conway, 2012; Grassini and Cassman, 2012). The transfer of knowledge in this area need to be made known to all stakeholders involved in cereals production to ensure sustainable cereal production.

\section{CONCLUSION AND RECOMMENDATIONS}

Cereals are crucial resources and in high demand in every part of the world both for food and non-food purposes. However, to sustain its utilisation to meet both present and future demand, much attention must be paid to the sustainability and environmental issues surrounding it.

In addition to the ones discussed, the following should also be considered as priority factors: 
- Availability of cropland and land administration issues in developing countries must be addressed to ensure sustainable cropping practices.

- Political contingencies and weak policies in the developing countries should be strengthened for enabling environment for production of cereals.

- Providing support for the adoption of new technologies such as improved variety of seeds and other inputs to boost production.

- Market forces of demand and supply must also be considered together with the global economic situation which is capable of disrupting trade and wealth of a nation.

\section{REFERENCES}

Awika J.M. (2011). Major cereal grains production and use around the world. Available at: https://pubs.acs.org/doi/pdf/10.1021/bk-2011-1089.ch001, Accessed 28/05/2018

Bommarco R., Kleijn D. and Potts S.G. (2013). Ecological intensification: harnessing ecosystem services for food security. Trends in Ecol. Evol., 28 (4), 230-238

Chakraborty S. and Newton A.C. (2011). Climate change, plant diseases and food security: An overview. Plant Pathol., 60 (1), 2-14. https://onlinelibrary.wiley.com/doi/ full/10.1111/j.1365-3059.2010.02411.xConwayG.2012

Conway G. (2012). One Billion Hungry: Can We Feed the World? New York: Cornel University Press, ISBN 0-8014-7802-2, 456 pp.

Dako D.Y. (1985) Cereal utilization in West Africa. In: Lásztity R. and Hidvégi M. (eds.), Amino Acid Composition and Biological Value of Cereal Proteins (pp. 27-43). Springer, Dordrecht. https://doi.org/10.1007/978-94-009-5307-9_2

Doring T.F., Annicchiarico P., Clarke S., et al. (2015). Comparative analysis of performance and stability among composite cross populations, variety mixtures and pure lines of winter wheat in organic and conventional cropping systems. Field Crops Research, 183, 235-245

Fernie J. and Pitkethly A.S. (1985). Resources, Environment and Policy (pp. 306-308). First Published in 1985 by Harper \& Row Ltd. Reprinted in this edition by Paul Chapman Publ. Ltd, 144 Liverpool Road London

Foley J.A. Ramankutty N. and Brauman K.A. (2011). Solutions for a cultivated planet. Nature, 484, 337-342. Available at: http://www.nature.com/articles/nature10452

FAO (1996). Food outlook, global information and early warning systems. Food and Agricultural Organization of United Nations. Available at: http://www.fao.org/ docrep/004/w3219e/w3219e00.html, Accessed 30-05-2018

FAO (2003). World Agriculture: towards 2015/2030. FAO perspective. Available at http://www.fao.org/docrep/005/y4252e/ y4252e04b.htm

FAO (2004). Global information and early warning system on food and agriculture. Available at: http://www.fao.org/ docrep/006/J2084e/j2084e01.html. Accessed 25/05/2018

FAO (2015). Social protection and agriculture: breaking the cycle of rural poverty. The state of food and agriculture 2015. Available at: http://www.fao.org/ publications/sofa/2015/en/, Accessed 28/05/2018

FAO (2018). World food situation, Food and Agriculture Organization of the United Nations. Available at: http:// www.fao.org/worldfoodsituation/csdb/en/, Accessed 31/05/2019

FAO (2019). Crop prospects and food situation Quarterly Global Report no. 4, Dec. 2019. Rome

FAO (2020). World food situation. FAO Cereal Supply and Demand Brief, Available at: http://www.fao.org/ worldfoodsituation/csdb/en/, Accessed 15/08/2020
Grsssini P. and Cassman K.G. (2012). High-yield maize with large net energy yield and small global warming intensity. Proc. National Academy of Science of the United States of America, 109, 1074-1079

Haussmann B.I., Fred-Rattunde H., Weltzien-Rattunde E., Traoré P.S.C., Vom Brocke K. and Parzies H.K. (2012). Breeding strategies for adaptation of pearl millet and sorghum to climate variability and change in West Africa. Journal of Agronomy \& Crop Science, 198 (5), 327-339

International Union for Conservation of Nature, IUCN. (2014). The IUCN red list of threatened species. Version 2014.3. Available at: http://www.iucnredlist.org

Jones J.M. and Sheats D.B. (2016). Consumer trends in grain consumption. Available from: http://scitech connect.elsevier.com/wp-content/uploads/2015/12/Consumer -Trends-in-Grain-Consumption-1.pdf, Accessed 25/05/2018

Kissinger G, Herold M. and De Sy V. (2012). Drivers of deforestation and forest degradation: a synthesis report for REDD+ policymakers, pp. 29-34. Lexeme Consulting, Vancouver Canada

Lambin E.F. and Meyfroidt P. (2011). Global land use change, economic globalization, and the looming land scarcity. Proc. Natl. Acad. Sci. USA, 108, 3465-3472. http://europepmc.org/ articles/PMC3048112

Larson D.F., Otsuka K., Kajisa K., Estudillo J. and Diagne A. (2010). Can Africa replicate Asia's green revolution in rice? Washington DC: World Bank, Dev. Res. Group, Agric. \& Rural Dev. Team. https://www. scribd.com/ document/44014020/Can-Africa-ReplicateAsia-s-Green-Revolution-in-Rice. Accessed 30/05/2018

Mille B., Belhaj Fraj M., Monod H. and De VallavieillePope C. (2006). Assessing four-way mixtures of winter wheat cultivars from the performances of their two-way and individual components. European Journal of Plant Pathology, 114 (2), 163-173

OECD/FAO (2016). Cereals. In: OECD-FAO Agricultural Outlook 2016-2025 (pp. 98-123). OECD Publishing, Paris. https://www.oecd-ilibrary.org/docserver/ agr_outlook-2016en.pdf?expires=1527715340\&id=id\&accname= guest\&checksum=6E5F9CA4D299C70D1BC1B30DD2FB30C3

Reay D.S., Davidson E.A., Smith K.A., et al. (2012). Global agriculture and nitrous oxide emissions. Nature Climate Change, 2, 410-416. Available at: file:///C:/Users/ oloru/AppData/Local/Packages/Microsoft.MicrosoftEdge_8 wekyb3d8bbwe/TempState/Downloads/Reayetal2012.pdf

Stevenson J.R., Serraj R. and Cassman K.G. (2014). Evaluating conservation agriculture for small-scale farmers in Sub-Saharan Africa and South Asia. Agric. Ecosys. Environ., 187, 1-10. Available at: https:// www.deepdyve.com/lp/elsevier/ evaluating-conservationagriculture-for-small-scale-farmers-in-sub-wuvcaoe6BG

Tilman D., Fargione J. and Wolff B. (2001). Forecasting agriculturally driven global environmental change. Science, 292, 281-284. Available at: http://science.sciencemag.org/content/292/5515/281.full

Tilman D., Balzer C., Hill J. and Befort B.L. (2011). Global food demand and the sustainable intensification of agriculture. Proc. Natl. Acad. Sci. USA, 108, 20260-20264. http://europepmc.org/articles/PMC3250154

Wakatsuki T., Obalum S.E. and Igwe C.A. (2011). Multifunctionality of sawah eco-technology: why sawah-based rice farming is critical for Africa's green revolution. Presented at the 1st Int. Conf. on Rice for Food, Market \& Dev. (organized by Rice-Africa), 3-5 Mar. 2011, Raw Materials Research \& Development Council Corporate Headquarters, Abuja, Nigeria

Wrigley C.W. (2016). An Overview of the Family of Cereal Grains Prominent in World Agriculture. Encyclopedia of Food Grains. Edited by C.W. Wrigley, H. Corke, K. Seetharaman and J. Faubion. Elsevier, ISBN 978-0-12-394786-4 